\title{
Los revocos de cal de las fachadas de la plaza de la Corredera de Córdoba
}

\author{
The lime renderings from plaza de la \\ Corredera, Córdoba
}

\author{
T. GONZÁLEZ LIMÓN*, M. ALVAREZ de BUERGO BALLESTER** \\ (*)Laboratorio Central de Estructuras y Materiales. Centro de Estudios y Experimentación de Obras Públicas (CEDEX). \\ Ministerio de Fomento.
}

Fecha de recepción: 12-IV-01

Fecha de aceptación: 5-XII-01

ESPAÑA

\section{RESUMEN}

En este estudio se analizan las causas de las patologias de los revocos de cal de las fachadas de la Plaza de la Corredera. Para ello se ha realizado el análisis mineralógico y químico de los materiales de construcciónfábrica de ladrillo y mortero de revestimiento- y se han determinado sus propiedades fisicas, hídricas y mecánicas. Mediante la comparación de los resultados obtenidos en los materiales inalterados y en los alterados, asi como una vez analizadas las materias primas utilizadas en la realización del revoco, se ha podido establecer que la alteración de este último está relacionada con la existencia de compuestos salinos (yeso, halita) que, presentes en el substrato de fábrica de ladrillo, se han exudado por saturación de agua de la misma. La precipitación de las sales (halita, hexahidrita, epsomita) en su migración hacia el exterior ha sido la principal responsable de las formas de alteración -eflorescencias, costras, arenización, abombamientos, descamaciones- que aparecen sobre los revocos de estudio.

\section{SUMMARY}

The causes of the pathologies found on the lime renderings from Plaza de la Corredera façades are analysed in this study. For this purpose, the mineralogical and chemical analyses of the building materials -brickwork and rendering mortar-has been carried out, as well as their physical, hydric and mechanical properties have been determined. The obtained results from both unaltered and altered materials, and the analysis of the rendering's raw materials, have allowed us to establish that rendering deterioration is connected to the presence of saline compounds (gypsum, halite), which existing in the brickwork substratum, have been removed due to the water saturation of such brickwork. The main cause responsible of the alteration forms efflorescences, crusts, grain-disintegration, bulging, flakingfound on the renderings, has been the salts precipitation (halite, hexahydrite, epsomite) in their way towards the external surface.
PALABRAS CLAVE: mortero, revoco, cal, fábrica de ladrillo, alteración

\section{INTRODUCCIÓN}

En este trabajo se aborda el estudio de los revocos de las fachadas de la Plaza de la Corredera, construcción del siglo XVII, constituida por una serie de edificaciones de 4 plantas de altura que conforman una plaza de planta rectangular. En planta baja se disponen arcos de medio punto -plaza porticada-, mientras que
KEYWORDS: mortar, rendering, lime, brickwork, alteration

\section{INTRODUCTION}

This paper undertakes the study of the façades renderings from Plaza de la Corredera, which dates from the XVIIth century and is comprised of a series of four-storey constructions around a rectangular square. The ground floor features an arcade formed by semicircular arches-arcade square-while the other 
las otras 3 plantas superiores de las fachadas de estudio, presentan un ritmo de huecos de dos balcones por arco.

$\mathrm{El}$ aspecto uniforme y regular que presenta actualmente la plaza es el resultado de circunstancias muy variadas que ha ido sufriendo a lo largo de su historia (1). En origen fue un vacío urbano, que posiblemente surge como un cruce de caminos, transformándose posteriormente a lugar de encuentro de la población. La plaza va adquiriendo con el tiempo mayor importancia en la vida de la ciudad; en el siglo XVII se unifican las características arquitectónicas de los edificios que conforman la plaza mediante la construcción unitaria de la primera crujía, con la excepción del edificio que albergaba la cárcel y de los edificios denominados "Casas de Doña Ana Jacinto". Posteriormente ha sufrido una serie de adaptaciones, entre las que destacan la relativamente reciente construcción de un mercado subterráneo que ocupa la casi totalidad de la plaza y que eleva el plano del pavimento de la misma.

La fachada exterior es, en general, de fábrica de ladrillo macizo con juntas de mortero de cal. En el momento de llevar a cabo el estudio, parte de las fachadas norte y oeste se habían revocado recientemente de acuerdo al proyecto de rehabilitación de la plaza. Señalar en este punto que durante el proceso de ejecución de los revocos, las fachadas de estudio estuvieron sometidas a abundantes precipitaciones en forma de lluvia, con falta de medidas de protección. El revoco, con un acabado en tonos crema, incorporaba en el recercado de los huecos, una pintura al fresco de color almagre. Dichos revocos manifestaron ciertas patologías poco después de su puesta obra, lo que motivó el inicio de esta investigación, que tiene, como principal objetivo, el análisis de las causas de las patologias observadas.

\section{METODOLOGÍA DE TRABAJO}

La metodología de trabajo llevada a cabo ha sido la siguiente:

- análisis de las patologías existentes sobre los revocos - caracterización del material (ladrillo, mortero de rejuntado y revoco), tanto del inalterado como del alterado

- análisis de las materias primas del revoco

- determinación de las causas de las patologías

A continuación se relacionan las técnicas utilizadas, los ensayos realizados, y las normas seguidas:

- Caracterización mineralógica del ladrillo, mortero de junta, revoco y pintura al fresco mediante difracción de rayos $X(D R X)$, Siemens D-5000, ${ }^{\circ} 2$, tubo de ánodo de $\mathrm{Cu}$; software analítico DIFFRAC AT versión EVA V 3.2. three façades floors above are characterized by regularly spaced openings consisting of two balconies per arch.

The uniform and regular appearance the Plaza shows today is a consequence of several circumstances it has gone through its history (1). Originally it was an urban void, which possibly began as a crossroads, evolving later to a population meetpoint. The Plaza gets more and more importance in the city life; the architectonic characteristics of the buildings around the Plaza get unified in the XVIIth century by the construction of the first corridor, with the exception of the prison building and the building named "Casas de Doña Ana Jacinto". Later on, the Plaza has gone through some modifications, among which the relatively modern construction of an underground market which occupies almost the totality of the square surface can be pointed out, rising the pavement surface.

The exterior façade consists, for the most part, of brick masonry (solid units) with lime mortar joints. At the moment this study was being carried out, part of the North and West façades had been rendered according to the rehabilitation project of the Plaza. It must be pointed out that during the rendering execution process, the building façades were subjected to intense precipitations (raining), in absence of protection devices. To the rendering, with a beige-colouring finishing, a red ochre colouring lime painting was added when placed around the void frames. Such renderings showed some pathologies just after their setting up, which are the matter of this research, with the main aim of analysing the causes of their existence.

\section{WORKING METHODOLOGY}

The methodology of work carried out has been the following:

- Analysis of the existing pathologies on the renderings - Materials characterization (brick, pointing mortar and render), both unaltered and altered material

- Analysis of the rendering's raw materials

- Determination of the pathologies causes

The techniques, tests and guidelines are mentioned the next:

- Mineralogical characterization of the brick, joint mortar, rendering and lime-painting by X-Ray Diffraction (XRD), Siemens D-5000, ${ }^{\circ}$, copper anode tube; analytical software DIFFRACAT, EVA V 3.2 version. 
Análisis de muestra total. En los morteros se realizaron análisis tanto de muestra total (aglomerante y áridos), como análisis de la fracción enriquecida (aglomerante).

- Ensayo de adherencia in situ del revoco respecto a la fábrica de ladrillo mediante medidor de adherencia electrónico de enlucidos y revestimientos

(NEURTEK), con sufridera de $50 \mathrm{~mm}$ de diámetro, según UNE 83.822-95EX (2), y ensayo de adherencia sobre probetas de fábrica de ladrillo y revoco en laboratorio (3).

- Determinación de la capacidad de eflorescer de los ladrillos según UNE 67.029-95EX (4)

- Ensayos de absorción y desorción de agua en el ladrillo según recomendaciones NORMAL 7/81 (5) y 29/88 (6), respectivamente.

- Determinación de la porosidad abierta o accesible al agua $\left(\mathrm{n}_{0}\right)$ del ladrillo y del revoco según recomendaciones de la RILEM (1980) (7).

- Determinación de la permeabilidad al vapor de agua en probetas de revoco con y sin el acabado de pintura al fresco según recomendación NORMAL 21/85 (8).

- Análisis granulométrico de los áridos del mortero de revoco según BS 1199-86 (9).

- Determinación de la reactividad de los áridos dolomíticos del mortero de revoco según norma UNE 146507:1998 EX (10).

- Determinación del contenido en cloruros y sulfatos en el ladrillo, mortero de junta y revoco mediante analizador de carbono y azufre (LECO, CS-44) y complexometrías (valorador automático METHROM 670).

- Análisis del agua utilizada en la preparación del mortero de revoco según EH-91 (11).

- Determinación de compuestos orgánicos en la pintura al fresco mediante espectroscopía de infrarrojos por Transformada de Fourier (FTIR) (NICOLET FTIR 310).

\section{DESCRIPCIÓN DE LAS PATOLOGÍAS}

Las patologías existentes en los revocos al abordar este estudio son las que se describen a continuación:

Eflorescencias de color blanco. Aparecen sobre los dos tipos de acabado del revoco, el de tonos claros y el de color rojo, aunque son más visibles lógicamente sobre el último. Su textura es esponjosa y pulverulenta. Están localizadas fundamentalmente en dos bandas: en las partes inferiores de las jambas de los balcones y en los dinteles de los mismos.

Costras blanco-amarillentas. Aparecen principalmente sobre el revoco de color claro. Su aspecto es cristalino-vítreo y se presentan totalmente adheridas a
Total-sample analysis. In mortars, total-sample analysis (binding and aggregates), and enriched fraction analysis (binding) have been carried out.

- In situ pull-out testing of the rendering in relation to the brickwork, with an electronic adherence measurement device of renderings (NEURTEK), with a $50 \mathrm{~mm}$-diameter coupling device, according to UNE 83.822-95EX (2), and adherence testing on specimens (brickwork and rendering mortars) in laboratory (3).

- Determination of the brick efflorescences capacity according to UNE 67.029-95EX (4)

- Water absorption and evaporation tests of bricks according to NORMAL recommendations $7 / 81$ (5) and 29/88 (6), repectively.

- Open porosity or porosity accessible to water (no) determination on bricks and renderings according to RILEM recommendations (1980) (7).

- Determination of the water vapour permeability in rendering specimens, with and without the lime painting finishing, according to the NORMAL recommendation 21/85 (8).

- Grain size distribution analysis of the rendering mortar aggregates according to BS 1199-86 (9).

- Determination of the reactivity of the rendering mortar dolomitic aggregates according to the UNE 146507:1998 EX (10).

- Chlorides and sulphates content determination on bricks, joint mortars and renderings by a carbon and sulphur analyzer (LECO, CS-44) and complexometries (authomatic valorizer METHROM 670).

- Analysis of the water used to prepare and mix the rendering mortar according to EH-91 (11).

- Determination of organic compounds in the lime painting by Fourier-Transformed Infrared Spectroscopy (FTIR) (NICOLET FTIR 310).

\section{PATHOLOGIES DESCRIPTION}

When beginning this study, the existing pathologies found in the renderings are described next:

White efflorescences. These appear on both the beige and the red finishing layer of the rendering, especially more visible on the red one. Their texture is spongy and powdery. They are basically located along two fringes: in the lower part of the jambs of the balcony openings and in the lintels of the balcony openings.

White-yellowish crusts. These appear mainly on the light coloured render. They have a crystalline appearance and 
la capa de acabado. Son más abundantes en la fachada norte $y$, al igual que las eflorescencias, se localizan en las jambas y dinteles de los huecos de los balcones, y en la parte inferior de las zonas de unión entre los balcones.

Tanto las eflorescencias de color blanco como las costras blanco-amarillentas fueron analizadas en un primer estadio del trabajo con objeto de establecer las pautas de la investigación, si bien los resultados se expondrán en el apartado de caracterización de materiales.

Descamaciones. Aparecen acompañando a las eflorescencias de color blanco y principalmente sobre la pintura roja.

Arenización y pulverización. Los fenómenos de arenización se observan en dos zonas: en las partes inferiores de las jambas de los balcones, y en algunos puntos en los cuales se ha realizado una cata.

Manchas de color ocre-anaranjado o rojizo. Aparecen por debajo de los balcones, a la altura de los forjados, principalmente en la fachada norte.

Ampollas. Formación de ampollas sobre el mortero de revestimiento que en muchos casos se fisuran y terminan por despegarse y desprenderse.

\section{CARACTERIZACIÓN DE LOS MATERIALES}

La caracterización de los materiales se llevó a cabo tanto sobre muestras de las fachadas consideradas como sanas o inalteradas, como sobre muestras de materiales claramente alterados, con objeto de establecer los procesos y reacciones de deterioro que han tenido lugar y los factores que intervienen en los mismos. Los materiales analizados fueron: ladrillo, mortero de rejuntado, revoco (las tres capas del revoco y la pintura al fresco de color rojo). Además, se analizaron las materias primas utilizadas para la confección de los morteros de revoco (cal, áridos y agua), y los morteros de revoco preparados.

\subsection{Caracterización de los materiales inalterados}

En primer lugar se ha realizado la caracterización de los materiales de construcción "inalterados": ladrillo, mortero de junta y revoco. Este último, está constituido por tres capas: la capa base (MB), de 8,7 mm de espesor, la capa intermedia (MI), de 3,9 mm de espesor, y la capa de acabado (MA), con un are fully adhered to the render's finishing layer. They are more abundant on the north façade, and are located, as efflorescences, in the jambs and lintels of the balcony openings, and on the lowest part of the balconies joint areas.

Both white coloured efflorescences and white-yellowish crusts were analysed in a first stage of this work in order to establish a research plan, showing the results in the chapter of materials characterization.

Flaking phenomena. These appear together with the white efflorescences and are especially visible on the red painting.

Grain-disintegration ("sanding") and powdering phenomena. These can be observed in two areas: the lowest part of the balcony jambs and in certain areas in which sampling has been carried out.

Red and orange-ochre stains. These are found under the balconies, around the floorings, mainly on the north façade.

Blisters. Blisters form on the rendering mortar, which in many cases present fissures, and finally get apart and detached, falling down.

\section{MATERIALS CHARACTERIZATION}

Materials characterization was carried out in samples from façade, both in those considered sane or unaltered, and those materials notably altered, with the aim of establishing the deterioration processes and reactions which have taken place, as well as the factors taking part in them. The materials analysed were: brick, joint mortar and renders (the three rendering layers and the red lime paint). Raw materials used to prepare the rendering mortars were also analysed (lime, aggregates and water), as well as the 'ready-to-use' rendering mortars.

\subsection{Characterization of the unaltered materials}

In a first step, an analysis of the unaltered building materials: brick, joint mortar and render-was carried out. The render consists of three layers: bottom layer $(M B)$, with a thickness of $8,7 \mathrm{~mm}$, middle layer (MI), of 3,9 mm-thick, and the 0,7 mm-thick finishing layer 
espesor de 0,7 mm. En algunas zonas, sobre esta última capa se ha añadido una pintura al fresco de color rojo.

En las tablas 1 y 2 se recogen los resultados obtenidos. $\mathrm{El}$ hecho de determinar el contenido en sulfatos y
(MA). In some areas, upon this top layer, a red fresco painting was added.

Tables 1 and 2 show the results obtained. The determination of the sulphates and chlorides content,

\section{TABLA 1/TABLE 1}

Mineralogía y contenido en sulfatos y cloruros de los materiales (Mineralogy and sulphates and chlorides content of the materials)

\begin{tabular}{|c|c|c|c|c|}
\hline \multicolumn{2}{|c|}{ MATERIAL } & $\operatorname{DRX}(X R D)$ & $\begin{array}{c}\text { SULFATOS (SULPHATES) } \\
(\%)\end{array}$ & $\begin{array}{c}\text { CLORUROS (CHLORIDES) } \\
(\%)\end{array}$ \\
\hline \multicolumn{2}{|c|}{ LADRILLO (BRICK) } & $\begin{array}{l}\text { Q, Cc, M, Ge, Wo, F } \\
\text { (Do, Gy, Ha, He) }\end{array}$ & $0,27-0,79$ & $0,01-0,78$ \\
\hline \multicolumn{2}{|c|}{$\begin{array}{l}\text { MORTERO DE JUNTA } \\
\text { (JOINT MORTAR) }\end{array}$} & $\mathrm{Q}, \mathrm{Cc}, \mathrm{F}, \mathrm{M}$ & $0,17-0,56$ & $0,02-0,21$ \\
\hline $\begin{array}{l}\text { REVOCO } \\
(R E N D E R)\end{array}$ & $\begin{array}{c}M B \\
M I \\
M A \\
\end{array}$ & $\begin{array}{c}\text { Dol, Cc } \\
\text { Dol, Cc } \\
\text { Dol, Cc }(\mathrm{Po})\end{array}$ & $\begin{array}{l}0,07 \\
0,12 \\
0,05 \\
\end{array}$ & $\begin{array}{l}0,01 \\
0,01 \\
0,02 \\
\end{array}$ \\
\hline \multicolumn{2}{|c|}{$\begin{array}{l}\text { PINTURA AL FRESCO } \\
\text { (LIME PAINTING) }\end{array}$} & Cc, Dol, Hal, Go, He & -- & -- \\
\hline
\end{tabular}

$\mathrm{Q}=$ cuarzo (quartz); $\mathrm{Cc}=$ calcita (calcite); $\mathrm{M}=$ mica (mica); $\mathrm{Ge}=$ gehlenita (gehlenite); Wo=wollastonita (wollastonite); $\mathrm{F}=\mathrm{feldespato}$ (feldspar); Dol=dolomita (dolomite); Gy=yeso (gypsum); $\mathrm{Ha}=$ halita (halite); $\mathrm{He}=$ hematites (hematites); Po $=$ portlandita (portlandite); $\mathrm{Go}=$ goethita (goethite).

$M B=$ capa base (bottom layer); $M I=$ capa intermedia (middle layer); $M A=$ capa de acabado (finishing layer).

TABLA 2/TABLE 2

Ensayo de adherencia/(Pull-out test)

\begin{tabular}{|c|c|c|c|}
\hline $\begin{array}{c}\text { Testigo } \\
\text { (Test-specimen) }\end{array}$ & $\begin{array}{c}\mathrm{N}^{0} \text { ensayo } \\
\text { (Number of test) }\end{array}$ & $\begin{array}{c}\text { Zona de rotura } \\
\text { (Breaking area) }\end{array}$ & $\begin{array}{c}\text { Adherencia }\left(\mathrm{N} \cdot \mathrm{mm}^{-2}\right) \\
(\text { Pull-out })\end{array}$ \\
\hline TA-1 & 1 & $\mathrm{MI}$ & 0,195 \\
& 2 & $\mathrm{MB} / \mathrm{F}$ & 0,323 \\
& 3 & $\mathrm{~F}$ & 0,351 \\
& 4 & $\mathrm{MA} / \mathrm{MI}$ & 0,362 \\
\hline TA-2 & 1 & $\mathrm{MB} / \mathrm{F}$ & --- \\
& 2 & $\mathrm{~F}$ & 0,011 \\
& 3 & $\mathrm{~F}$ & 0,145 \\
& 4 & $\mathrm{~F}$ & 0,176 \\
\hline TA-3 & 1 & $\mathrm{~F}$ & --- \\
& 2 & $\mathrm{FB} / \mathrm{F}$ & 0,078 \\
& 3 & $\mathrm{MB}$ & 0,197 \\
& 4 & $\mathrm{MB}$ & 0,293 \\
\hline TA-4 & 1 & $\mathrm{MB}$ & 0,098 \\
& 2 & $\mathrm{MB} / \mathrm{F}$ & 0,236 \\
& 3 & $\mathrm{~F}$ & 0,062 \\
& 4 & $\mathrm{MB} / \mathrm{F}$ & 0,259 \\
\hline TA-5 & 1 & $\mathrm{~F}$ & 0,242 \\
& 2 & $\mathrm{~F}$ & 0,149 \\
& 3 & $\mathrm{~F}$ & 0,221 \\
& 4 & 0,271 \\
\hline
\end{tabular}

$M B=$ capa base (bottom layer); $M I=$ capa intermedia (middle layer); $M A=$ capa de acabado (finishing layer); $F=$ fábrica de ladrillo (brickwork); --- rotura antes de iniciar el ensayo (failure before testing) 
cloruros, y no de otros aniones, se debe a que antes de iniciar esta fase de caracterización, se analizaron las sales que aparecían sobre el revoco, identificando, como se verá más adelante, la presencia de halita (cloruro sódico) y de hexahidrita y epsomita (ambos, sulfatos magnésicos hidratados). Por tanto, determinando el contenido en sulfatos y cloruros en el resto de los materiales, lo que se pretende es determinar la fuente de dichas sales.

Respecto al ladrillo, lo que más interesaba era conocer su mineralogía básica, el contenido en cloruros y sulfatos (tabla 1), así como la capacidad que tendrían de hacer circular por su sistema poroso soluciones salinas. Para esto último era primordial conocer la porosidad de los ladrillos, su cinética de absorción y de desorción de agua, y su capacidad para producir eflorescencias. La mineralogía de los ladrillos indica que la cocción del material arcilloso se realizó a una temperatura aproximada entre $800^{\circ}$ y $900^{\circ} \mathrm{C}$ por la presencia de la paragénesis calcita-gehlenitawollastonita. Sólo en casos puntuales se ha detectado la presencia de dolomita, yeso, halita y hematites. De todos los materiales analizados (ladrillo, mortero de junta y revoco), el ladrillo es el que presenta el contenido más elevado en sulfatos y cloruros. Los ladrillos tienen una porosidad abierta o accesible al agua muy elevada $(43 \% \pm 14)$ pero característica de los materiales cerámicos de construcción. Dicha porosidad es la responsable de la elevada capacidad de absorción de agua de los ladrillos (figura 1). Del contenido total de agua absorbido por los ladrillos, el $80-85 \%$ es absorbido en los primeros 30 minutos; lo cual indica que los ladrillos absorben el agua rápidamente. Por otra parte, los ladrillos tienen una baja capacidad de evaporar el agua absorbida (figura 1). Así, transcurridas 24 horas desde el inicio del ensayo, las probetas sólo perdieron entre un $13 \%$ y un $26 \%$ del agua absorbida, pero, al finalizar el ensayo (12 días), 3 de ellas alcanzan un contenido en agua inferior al $2 \%$, mientras que una cuarta probeta queda con un contenido residual por encima del $10 \%$. Una vez realizado el ensayo de eflorescencias, los ladrillos se pueden calificar como ligeramente eflorescidosLos resultados obtenidos en el ensayo de eflorescencia permiten calificar a los ladrillos como ligeramente eflorescidos (4)

El mortero de junta está constituido por un aglomerante de cal y árido de naturaleza silícea (cuarzo, feldespatos y micas); presenta cierto contenido en sulfatos y cloruros, aunque menor que el ladrillo.

La composición mineralógica y química de las tres capas del revoco es muy similar. Es un mortero de cal con árido calizo y dolomítico. Su contenido en sulfatos es bajo (la capa intermedia es la que presenta el contenido más alto de las tres), y menor aún el de and no other anions content, is due to the result of a previous analysis of the existing salts on the render which was carried out before this characterization phasis was performed, identifying, as it will be detailed later, the presence of halite (sodium chloride), and hexahydrite and epsomite (both of them being hydrated magnesium sulphates). Thus, the identification of such salts content is the aim of determining the sulphates and chlorides content in the rest of the materials.

In relation to brick, the most interesting aspect was to know its basic mineralogy, its chlorides and sulphates content (table 1), as well as its capability of allowing the saline solution circulation through its porous system. For this reason it was essential to know the bricks porosity, their water absorption kinetics and their capability of producing efflorescences. Their mineralogy indicates that the clay material was fired at a temperature between $800^{\circ}$ and $900^{\circ} \mathrm{C}$, due to the presence of the calcite-gehlenite-wollastonite paragenesis. Only in very few cases dolomite, gypsum, halite and hematites have been detected. Brick is the material with the highest content in sulphates and chlorides from all the materials which have been analyzed (brick, joint mortar and render). Brick's open porosity is very high $(43 \% \pm 14)$. Such porosity is the responsible for the high capacity of water absorption of bricks (figure 1). Of the total water content absorbed by bricks, 80-85\% was absorbed in the first 30 minutes, indicating that bricks absorb water quickly. In the other hand, bricks also display a low capacity for evaporating the absorbed water (figure 1). It was thus found that 24 hours after the test started, brickspecimens only lost between $13 \%$ and $26 \%$ of the absorbed water, whereas at the completion of the test (12 days), 3 of the specimens reached a water content below $2 \%$, with a fourth specimen having a residual content above 10\%. Results obtained from the efflorescence test allow to classify the bricks as slightly effloresced (4).

Joint mortar is composed by lime binding and silicious aggregates (quartz, felspars and micas); it shows a lower sulphates and chlorides content than bricks.

Mineralogical and chemical composition of the three rendering layers is very similar. It is a lime mortar with calcitic and dolomitic aggregates. Sulphates content is low (middle layer has the highest content), and even lower is the chlorides content. Fresco painting consists 
cloruros. La pintura al fresco es una pintura a la cal con compuestos de hierro (goethita y hematites) como pigmentos minerales. Se ha detectado la presencia de halita. Ya que dicha pintura presenta fenómenos de descamación, se llevó a cabo el ensayo de permeabilidad al vapor de agua para determinar si dicha patología se debía a cierto grado de impermeabilización provocada por aplicación de la pintura, aunque los datos obtenidos $\left(224 \pm 93 \mathrm{~g} \cdot \mathrm{m}^{-2} \cdot 24 \mathrm{~h}\right.$ para el revoco con acabado en color crema y $178 \pm 31 \mathrm{~g} \cdot \mathrm{m}^{-2} \cdot 24 \mathrm{~h}$ para el revoco con acabado rojo) no permiten confirmar este hecho. Además, mediante FTIR no se ha podido constatar la presencia de ningún compuesto de origen orgánico que pudiera haberse añadido a la pintura. La porosidad accesible al agua del revoco es del $27,1 \%$.

Mediante el ensayo de adherencia se evalúa la resistencia entre las distintas capas de revoco, y entre el revoco y el soporte -fábrica de ladrillo-. Se ha llevado a cabo el ensayo in situ (figura 2) obteniendo un valor de tracción de $0,10 \pm 0,12 \mathrm{~N} \cdot \mathrm{mm}^{-2}$ para el revoco respecto a la fábrica de ladrillo, y en laboratorio (3) (tabla 2), constatándose la correspondencia entre los datos obtenidos en ambos casos, aunque ligeramente superiores los obtenidos en laboratorio. Para analizar la adherencia entre las distintas capas, se ha realizado el ensayo 4 veces consecutivas sobre cada probeta, procediendo a la adhesión de la zona separada después de cada arrancamiento; de esta forma se determina la capa que presenta menor adherencia y las sucesivas. De los datos que se muestran en dicha tabla se deduce que la unión más débil, por ser la rotura más frecuente en los testigos ensayados, es la existente entre la capa base del mortero de revoco y la fábrica de ladrillo (valores de tracción comprendidos entre 0,062 y $0,323 \mathrm{~N} \cdot \mathrm{mm}^{-2}$ ). No es frecuente la rotura por la unión entre las capas del revoco, y, de forma ocasional, se produce por el interior de las mismas.

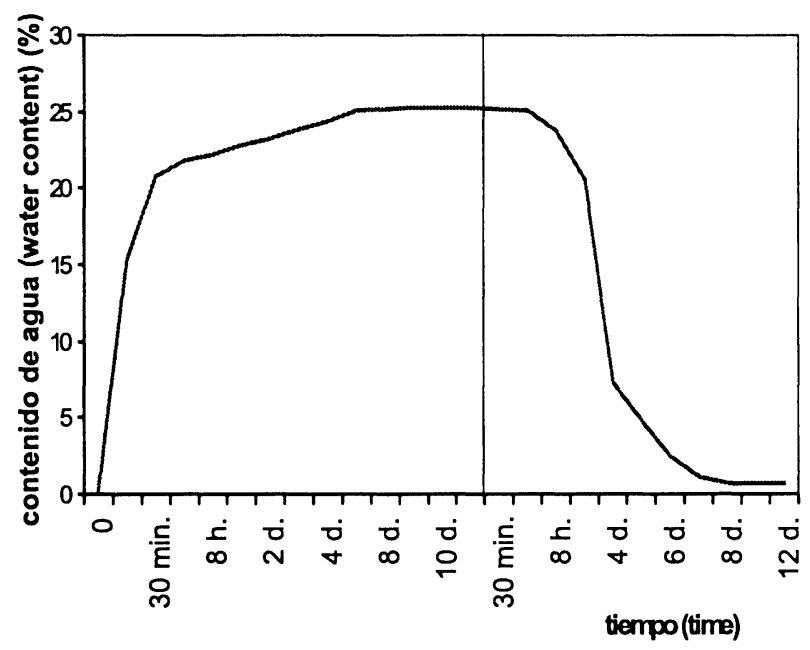

Figura 1.- Curva de absorción-desorción de agua de los ladrillos. Figure 1.- Water absorption and evaporation of bricks. of a lime painting with iron compounds (goethite and hematites) as mineral pigments. The presence of halite has been identified. The flaking phenomena experimented by such painting was the reason of performing the water vapour permeability tests, in order to determine whether such pathology was due to any water-proofing effect caused by the painting application, although the obtained data $\left(224 \pm 93 \mathrm{~g} \cdot \mathrm{m}^{-2} \cdot 24 \mathrm{~h}\right.$ for the beige finishing rendering and $178 \pm 31 \mathrm{~g} \cdot \mathrm{m}^{-2} \cdot 24 \mathrm{~h}$ for the red finishing rendering) do not allow to confirm this hypothesis. Besides, the use of the FTIR technique has not proved the presence of any organic compound which could have been added to the painting. Porosity accessible to water of the rendering mortar is $27.1 \%$.

The adherence test assesses the degree of adhesion among the different layers of the render, and between the render and the brick masonry. The test was performed both in situ (figure 2), with a pull-out value of $0,10 \pm 0,12 \mathrm{~N} \cdot \mathrm{mm}^{-2}$ for the rendering in relation to the brickwork, and in laboratory (3) (table 2), showing the similarity of the results obtained in both cases, slightly higher those obtained in the laboratory. In order to analyze the adherence among the different layers, each specimen was subjected to 4 consecutive tests, readhering and rebonding the separated pieces after being pulled off, so as to determine which of the layers showed the weakest bonding. From table 2, it can be deduced that the weakest bond, as it is the most repeated failure of the tested specimens, is the contact between the rendering mortar and the brickwork (pull-out values between 0,062 and 0,323 $\mathrm{N} \cdot \mathrm{mm}^{-2}$ ). Failure between rendering layers bonding is not usual, and eventually it is produced through the interior of them.

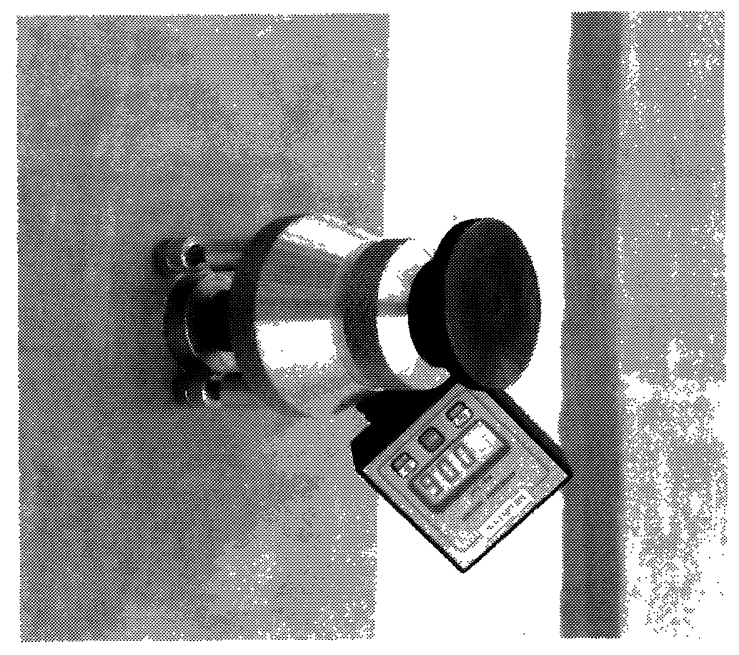

Figura 2.- Ensayo para la determinación de la adherencia in situ. Figure 2.- In situ pull-out test. 


\subsection{Caracterización del material alterado}

Se ha llevado a cabo el estudio de las 3 capas del revoco "alterado" y de las sales que aparecen sobre la capa de acabado del revoco, obteniéndose los resultados expresados en la tabla 3. Al no presentar patología alguna ni el mortero de junta ni el ladrillo, sólo han sido analizados como materiales inalterados. Las eflorescencias salinas pulverulentas de color blanco están constituidas por sulfato de magnesio con diferentes grados de hidratación: hexahidrita $\left(\mathrm{SO}_{4} \mathrm{Mg} \cdot 6 \mathrm{H}_{2} \mathrm{O}\right)$ y epsomita $\left(\mathrm{SO}_{4} \mathrm{Mg} \cdot 7 \mathrm{H}_{2} \mathrm{O}\right)$. Las costras blanco-amarillentas, de textura vítrea, que aparecen sobre el revoco de acabado color claro están compuestas por halita (cloruro de sodio).

Mientras que en las muestras de revoco inalterado o sano, la portlandita sólo aparecía puntualmente en una muestra, ésta aparece en todas las muestras de mortero de la capa base, tanto en los análisis de muestra total como en los de fracción enriquecida. También aparece halita en las capas intermedias y de acabado como principal diferencia frente a las muestras inalteradas. Mientras que el contenido en sulfatos en las muestras alteradas es sensiblemente superior a las muestras inalteradas, el contenido en cloruros ha aumentado notablemente.

\subsection{Análisis de las materias primas del revoco: mortero preparado, cal, áridos y agua}

Para comprobar si las materias primas eran las causantes de las patologías presentes en el revoco, se ha procedido al análisis de los morteros de revoco preparados, así como de los áridos, de la cal y del agua utilizados en la confección de los mismos (tabla 4).

La cal está mineralógicamente constituida por hidróxido cálcico y carbonato cálcico. Hay que señalar que la presencia de este último compuesto es resultado

\subsection{Characterization of the altered material}

The analysis of the 3 layers of the altered render was carried out, as well as of the existing salts on the finishing layer of the render, showing the results in table 3. As joint mortar and brick did not show any pathology, they were just analysed as unaltered materials. Whitish and powdery efflorescences are composed by magnesium sulphate with different hydratation degree: hexahydrite $\left(\mathrm{SO}_{4} \mathrm{Mg} \cdot 6 \mathrm{H}_{2} \mathrm{O}\right)$ and epsomite $\left(\mathrm{SO}_{4} \mathrm{Mg} \cdot 7 \mathrm{H}_{2} \mathrm{O}\right)$. The whitish-yellowish crusts, with a glassy texture, existing on the lightcoloured finishing layer of the render are composed by halite (sodium chloride).

While portlandite was detected only in one sample of the unaltered render, it has been identified in all samples taken from the bottom layer $(M B)$ of the altered render, both in total-sample and in enrichedsample analysis. The presence of halite in both middle and finishing layers is the main difference with respect to the unaltered samples. Sulphates and chlorides content, especially this last one, is higher in altered samples than in unaltered ones.

\subsection{Analysis of the raw materials of the render: 'ready-to-use' mortar, lime, aggregates and water}

The analysis of the ready-to-use mortars, as well as of the aggregates, lime and water used for the mixing process, has been carried out so as to determine their posible role in causing the rendering pathologies (table 4).

Lime is composed of calcium hydroxide and carbonate. The presence of carbonates is due primarily to the actual processes of the testing. Water analysis reveals it can not

\section{TABLA 3/TABLE 3}

Mineralogía y contenido en sulfatos y cloruros de los materiales alterados (Mineralogy and sulphates and chlorides content of the alteral materials)

\begin{tabular}{|cccc|}
\hline Muestra (Sample) & DRX (XRD) & $\begin{array}{c}\text { Sulfatos (\%) } \\
\text { (Sulphates, \%) }\end{array}$ & $\begin{array}{c}\text { Cloruros (\%) } \\
\text { (Chlorides, \%) }\end{array}$ \\
Mortero capa base (MB) & Calcita, dolomita, portlandita & 0,10 \\
(Bottoms layer mortar, MB) & (Calcite, dolomite, portlandite) & 0,09 & 0,64 \\
Mortero capa intermedia (MI) & Calcita, dolomita, halita & 0,06 & 1,68 \\
(Middle layer mortar, MI) & (Calcite, dolomite, halite) & \\
Mortero capa acabado (MA) & Calcita, dolomita, halita & & \\
(Finishing layer mortar, $M A)$ & (Calcite, dolomite, halite) \\
Sales eflorescidas & Hexahidrita, epsomita & 0,20 & $-\cdots$ \\
(Effloresced salts) & (Hexahidrite, epsomite) & $-\cdots$ & - \\
\hline
\end{tabular}


Análisis de las muestras de las materias primas de los morteros del revoco

(Analisys of the raw materials of the rendering mortar)

Material

Mortero de la Capa Base (MB)

Bottom Layer Mortar (MB)

Mortero de la Capa Intermedia (MI)

Middle Layer Mortar (MI)

Mortero de la Capa de Acabado (MA)

Finishing Layer Mortar (MA)

Cal grasa (High calcium lime)

\section{Agua (Water)}

Árido grueso utilizado en la capa base (Coarse aggregate used in the bottom layer)

Árido fino, 0-1 mm, utilizado en la capa base y en la capa intermedia (Fine aggregate, $0-1 \mathrm{~mm}$, used in both bottom and middle layers)

Arido muy fino, 0-0,5 mm, utilizado en la capa de acabado (Very fine aggregate,0-0,5 $\mathrm{mm}$, used in the finishing layer)
Análisis (Analysis)

Dolomita, Calcita, Portlandita

(Dolomite, Calcite, Portlandite)

Dolomita, Portlandita, Calcita

(Dolomite, Portlandite, Calcite)

Portlandita, Dolomita, Calcita

(Portlandite, Dolomite, Calcite)

Portlandita, Calcita (Portlandite, Calcite)

Cumple requisitos exigidos en $\mathrm{EH}-91$ (11)

(Meets EH-91 requirements) (11)

Calcita

(Calcite)

Dolomita, Calcita

(Dolomite, Calcite)

Dolomita, Calcita, Minerales arcilla

(Dolomite, Calcite, Clay minerals)

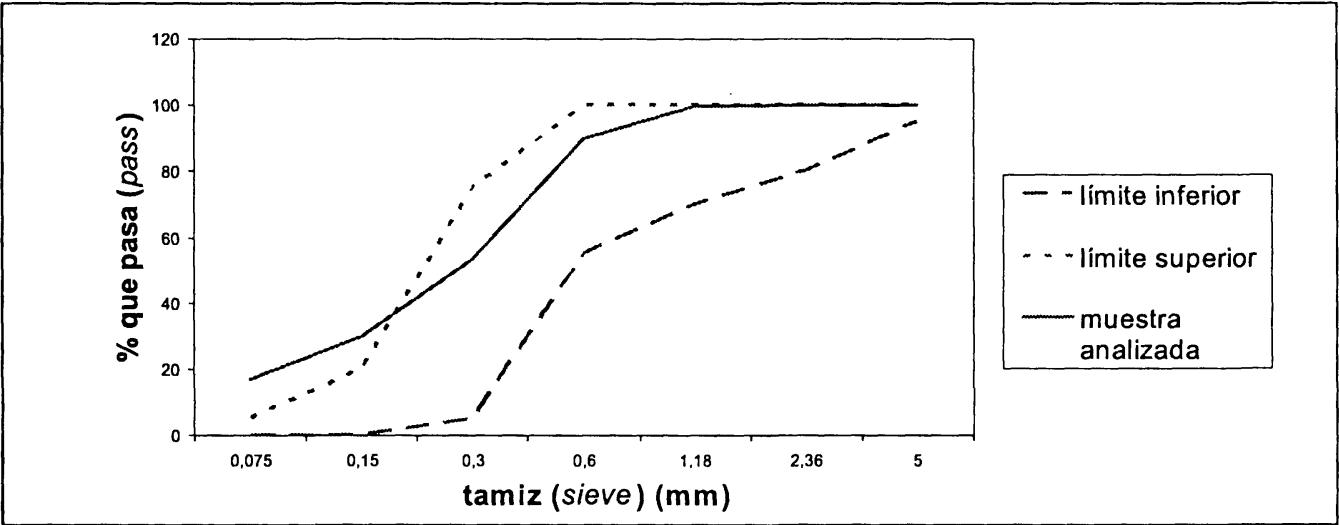

Figura 3.- Distribución granulométrica del árido fino, según BS 1199-86.

(Figure 3.- Grain size distributions of the fine aggregate, according to BS 1199-86.

del proceso de análisis de la cal. El análisis del agua utilizada revela que ésta no puede considerarse como elemento de aporte de posibles sales.

Con respecto a los áridos, el árido grueso es de naturaleza calcítica, mientras que los áridos fino y muy fino, contienen más dolomita que calcita. El árido muy fino, tiene, además, algo de minerales de arcilla. La distribución granulométrica (figura 3) del árido analizado (árido fino), es continua. Al carecer de una norma española específica para áridos de morteros de revestimiento, se ha recurrido a la norma británica (9), en la cual se especifican unos valores límite, superior e inferior, para la distribución granulométrica del árido, dependiendo la evaluación de resultados de la norma de análisis utilizada; en general, las desviaciones obtenidas be considered itself as a contributing element for possible salts.

As for the aggregates, the coarse sand is calcitic, while fine and very fine types contain more dolomite than calcite. The very fine sand also contains some clay minerals. The grain size distribution (figure 3) of the fine aggregate (the one that has been analyzed) is continuous. Due to the lack of an specific Spanish standard for rendering mortars aggregates, a British standard has been followed (9), in which limit values for the aggregate size distribution are specified, superior and inferior. The 'non reactivity' of 
son pequeñas y en relación a distintos tamices. Igualmente se confirma la no reactividad de los áridos $\mathrm{y}$, por tanto, se descarta que la patología presente en las fachadas haya sido originada por la reactividad de los áridos utilizados en el revoco frente a las condiciones del medio.

\section{ANÁLISIS DE LOS RESULTADOS}

Fábrica de ladrillo. Tanto el ladrillo como el mortero contienen en origen sulfatos y cloruros; en el ladrillo se ha detectado mediante DRX la presencia de yeso y halita. Los valores de porosidad y absorción de agua del ladrillo son elevados (absorbe el agua rápidamente y la pierde lentamente) (12). El ladrillo se clasifica como ligeramente eflorescido.

Revoco. El mortero de revoco es de cal con áridos calcíticos y dolomíticos; se ha detectado la existencia de portlandita, tanto en el mortero sano (capa de acabado-MA), como en el alterado (capa base-MB), lo cual se corresponde con un proceso de carbonatación incompleto. En algunos puntos en los cuales se ha realizado una cata en sección perpendicular al plano de fachada (desde el mortero de acabado del revoco hasta la fábrica de ladrillo), se ha observado una baja resistencia mecánica de la capa base del revoco. Esta patología se produce por el fraguado incompleto de dicha capa al colocar la siguiente (lo que se corrobora con la presencia de portlandita). La porosidad del revoco es inferior a la del ladrillo.

Las tres capas del mortero de revoco alterado presentan un contenido en cloruros claramente más elevado que en las correspondientes capas del mortero inalterado; respecto a los sulfatos, se observa un mayor porcentaje en la capa exterior del mortero alterado en relación al mortero inalterado.

Existe por tanto una relación directa entre la alteración de los morteros y la presencia de compuestos salinos, especialmente para el caso de los cloruros. Los sulfatos y cloruros han podido migrar desde la fábrica de ladrillo hacia el exterior en presencia de humedad y de determinadas condiciones ambientales, precipitar en forma de las sales pulverulentas y blanquecinas que se observan (hexahidrita y epsomita) o de costras (halita) y ser causantes de las patologías existentes.

Es necesario resaltar que las patologías existentes suelen estar asociadas a zonas de acumulación de humedad, y, por tanto, a la presencia de agua, ya que como se ha mencionado anteriormente, las abundantes y prolongadas lluvias, provocaron la saturación de la fábrica de ladrillo. Sobre la fábrica de ladrillo que no llegó a revestirse, no se apreció ninguna patología, ni siquiera la aparición de eflorescencias, lo cual apunta a aggregates has been confirmed, thus rejecting the possibility that aggregates reactivity could have been responsible for the façades 'pathologies.

\section{DISCUSSION OF RESULTS}

Brickwork. Both brick and mortar originally contain sulphates and chlorides; gypsum and halite have been detected in the brick by means of XRD. Porosity and water absorption values for bricks are high (they absorb water rapidly and evaporates it slowly) (12). Brick is classified as slightly effloresced.

Render. Rendering mortar is made of lime with calcitic and dolomitic aggregates; portlandite has been detected both in the unaltered mortar (finishing layer$M A)$, and in the altered one (bottom layer-MB), which indicates an incomplete carbonation process. In some areas, where a sampling perpendicular to-the-façade section was done (from the rendering finishing mortar to the brickwork), the rendering bottom layer showed a low mechanical strength. This pathology is produced by an incomplete curing of this bottom layer when setting the following layer (this is corroborated by the presence of portlandite). Render porosity is lower than brick porosity.

What was observed in all of the layers of the altered rendering mortar was a chloride content clearly higher than the content of the respective unaltered mortar; in relation to sulphates, they were found in a higher percentage in the altered finishing layer than in the unaltered one.

A direct relationship can therefore be deduced to exist between the mortar alteration and the presence of saline compounds, especially in the case of chlorides. Sulphates and chlorides could have migrated from brickwork towards the external surface thanks to humidity presence, and there precipitate, due to environmental conditions, as the powdering and withish salts that can be observed (hexahydrite and epsomite), or as crusts (halite), causing the various existing pathologies.

It must be highlighted that the described pathologies are related to areas of humidity acummulation, and therefore to the water presence, because, as it has been previously mentioned, long and abundant rains, provoked the brickwork saturation. The brickwork that was not rendered, did not show any pathology, not even efflorescences appearance, which points towards the fact 
que la aplicación del revoco sobre la fábrica de ladrillo constituye una causa directa de la aparición de dichas patologías.

Los fenómenos de arenización y pulverización se deben a mecanismos de cristalización de sales en el interior del material pero próximos a la superficie, y que tienen como consecuencia el desprendimiento de capas superficiales de material (descamación), debido al efecto cuñala presión generada, por el aumento de volumen de las sales al cristalizar o al hidratarse. Tanto en la capa intermedia como en la de acabado, los análisis realizados han detectado la presencia de cloruro sódico (halita). Los fenómenos de descamación que experimenta la pintura al fresco de color rojo no deben relacionarse con un efecto de impermeabilización que la misma pintura pudiera crear sobre el revoco, sino más bien a fenómenos de cristalización de sales.

La adherencia entre las capas del revoco es aceptable, no siendo tan buena la adherencia del revoco a la fábrica de ladrillo.

Habiendo analizado las materias primas utilizadas para la confección de los morteros de revoco (agua, áridos y cal), así como los morteros preparados (capa base, intermedia y de acabado), no se ha encontrado ningún indicio de que dichos materiales sean responsables, por su propia naturaleza y composición, de la alteración que luego se observa en fachada.

\section{CONCLUSIONES}

Como conclusión, el proceso de las causas y evolución de la patología en los muros de fachada de la plaza de la Corredera, podría ser el siguiente:

La fabrica de ladrillo presenta una serie de características intrínsecas como son la elevada porosidad del ladrillo y cierto contenido en sulfatos y cloruros (en el caso de los sulfatos, en forma de yeso -sulfato de calcio dihidratado- y, en el caso de los cloruros, en forma de halita, cloruro sódico), compuestos, por otro lado, frecuentes en los materiales cerámicos. Estos dos factores, conjuntamente con la presencia de agua de lluvia (cuya entrada en las fachadas fue propiciada por la falta de medidas de protección) propician la disolución de las sales, que, con la ayuda de determinadas condiciones ambientales, migran hacia el exterior. Si al llegar a la superficie se encuentran con un revoco de menor porosidad que la fábrica de ladrillo, dificulta el traslado del agua a la superficie (para su evaporación). El agua retenida y acumulada tiene más tiempo para disolver las sales existentes. Parte de esta solución salina en su camino hacia el exterior, precipita en el interior de cada una de that the rendering execution on the brickwork is a direct cause of the origin of the pathologies.

Grain-disintegration and powdering phenomena are due to the salt crystallization processes in the material's interior but close to the surface, which provoke the superficial layers detachment (flaking) as a result of the generating pressure caused by the volume increase of the salts when crystallising or hydrating. By analyzing the middle and finishing layers, sodium chloride (halite) has been detected. The flaking phenomenon the red fresco painting undergoes can not be related to an impermeabilization effect created by the painting itself on the render, but to salt crystallization phenomena.

Adherence among rendering layers is acceptable; not so good is the adherence between the render and the brick masonry.

Having analyzed the raw materials used in the making up of the rendering mortars (water, aggregates and lime), as well as the ready-to-use mortars (bottom, middle and finishing layers), no signs have been found of such materials as being responsible, by their own nature and composition, of the existing alteration in the façades.

\section{CONCLUSIONS}

In conclusion, the causes and evolution of the pathologies observed in the façade walls of the Plaza de la Corredera, could be described as follows:

Brick masonry features a series of intrinsic characteristics as are the high porosity of the brick and certain sulphates presence (gypsum-dihytrated calcium sulphate-, and hexahydrite, epsomite, etc., magnesium sulphates in varying degrees of hydration), and chlorides content (halite, sodium chloride), compounds commonly found in ceramic materials. These two facts, together with the presence of water from rainings (water which came inside the façades helped by the lack of protection devices) help to the salts dissolution, which, along with certain environmental conditions, migrate towards the exterior. If the saline solutions, in their way towards the surface, meet a less-porous-render than the brickwork, it makes the water transport to the surface much more difficult (for its evaporation). The water that is thus retained, has a longer time to dissolve the existing salts. Part of this saline solution, in its way out, precipitates in the interior of each of the render layers; yet another part of the 
las capas del revoco; otra parte de la solución salina consigue alcanzar la superficie exterior del revoco y precipita en forma de eflorescencias. Las sales pulverulentas y blanquecinas que constituyen dichas eflorescencias se componen principalmente de sulfato de magnesio con diferentes grados de hidratación: hexahidrita y epsomita. Su origen puede deberse a la combinación de iones sulfato (yeso existente en el ladrillo) e iones magnesio (dolomita presente en el mortero de revestimiento). La solución salina que no llega al exterior y precipita debajo de la última capa de acabado del revoco, produce, debido al proceso de cristalización de sales, los fenómenos de arenización y pulverización, y que tienen como consecuencia el desprendimiento de capas superficiales de material, debido a 1 efecto cuña,la presión ejercida por el aumento de volumen de las sales al cristalizar o al hidratarse; en algunos casos produce el

"descascarillamiento" de la pintura al fresco.

\section{AGRADECIMIENTOS}

A la Consejería de Obras Públicas y Transportes de la Junta de Andalucía que financió el proyecto mediante convenio con el CEDEX.

A la División de Materiales Inorgánicos y al Sector de Ciencias de Materiales del Laboratorio Central del CEDEX por su colaboración en este trabajo. saline solution reaches the external surface of the rendering and precipitates as efflorescences. The whitish and powdery salts of such efflorescences are composed of magnesium sulphates in different degrees of hydration: hexahydrite and epsomite. Their origin can be attributed to the combination of sulphate ions (gypsum found in bricks), and magnesium ions (dolomite in the rendering mortar. The saline solution that does not reach the surface and precipitates under the finishing layer of the render produces, due to the salt crystallisation process, the grain-disintegration and powdering phenomena, resulting on the superficial layers detachment, due to the exerted pressure caused by the salts volume increase when crystallising or hydrating; the detachment and flaking of the fresco painting is also produced in some cases.

\section{ACKNOWLEDGMENTS}

To the Consejeria de Obras Públicas y Transportes of the Junta de Andalucia that financed the project by agreement with CEDEX.

To the Inorganic Materials Department and to the Materials Science Unity of the Laboratorio Central of $C E D E X$ for their collaboration in this project.

\section{BIBLIOGRAFÍA}

(1) Consejería de Obras Públicas y Transportes. Junta de Andalucía. Concurso de Anteproyectos. Plaza de la Corredera. Córdoba. 1999.

(2) AENOR. Norma UNE 83.822/95EX: Morteros. Métodos de ensayo. Morteros endurecidos. Determinación de la adherencia de los morteros de revoco y enlucido.

(3) F.J. Sáinz De Cueto, y S. Menéndez de Llano (2000) Ensayos de adherencia en morteros de revoco y restauración. Premio Calidad Arquitectura y Vivienda. Comunidad de Madrid. 99+98.

(4) AENOR. Norma UNE 67.029-95EX: Ladrillos cerámicos de arcilla cocida. Ensayo de eflorescencia

(5) ICR-CNR. Raccomandazione NORMAL 7/81: Assorbimento d'acqua per immersione totale. Capacità di imbibizione.

(6) ICR-CNR. Raccomandazione NORMAL 29/88: Misura della perdita per evaporazione dell'acqua assorbita dal materiale.

(7) RILEM: Recommended tests to measure the deterioration of stone and to assess the effectiveness of treatment methods. Materials and Structures, Vol. 75 (1980), pp. 175-253.

(8) ICR-CNR. Raccommandazione NORMAL 21/85: Permeabilitá al vapor d'acqua.

(9) British Standards: BS 1199-86: Specifications for building sands from natural sources-sands for mortars for plastering and rendering. (10) AENOR. Norma UNE 146507:1998 EX: Ensayo de áridos. Determinación de la reactividad potencial de los áridos. Método químico. Parte 2: Determinación de la reactividad álcali-carbonato.

(11) EH-91: Instrucción de hormigón estructural (1999).

(12) T. gonzález Limón, M. Alvarez de Buergo Ballester: Las particularidades de los materiales cerámicos. En "Manual de Diagnosis y Tratamiento de materiales Pétreos y Cerámicos", Colección Manual de Diagnosis, Vol. 5, pp.89-106. Collegi D'aparelladores i Arquitects Técnics de Barcelona, 1997. 